\title{
Indonesian Accounting Professionals and ASEAN's Mutual Recognition Arrangement; An Exploratory Study of Employability Factors
}

\author{
E Mayangsari' ${ }^{1}$, M Hermawan', V Juwono² \\ ${ }^{1}$ International Business Program, Management Department, BINUS Business School \\ International Undergraduate Program, Bina Nusantara University, Jakarta, Indonesia \\ ${ }^{2}$ Department of Public Administration, Faculty of Administrative Science, Universitas \\ Indonesia \\ 1vjuwono@ui.ac.id
}

\begin{abstract}
This paper attempts to explore employability factors of Indonesian accounting professionals in ASEAN region. A Career EDGE model is used as the employability framework. A qualitative approach is employed to obtain in-depth information and achieves insights from employer, employees, and experts. The finding showed that career development learning, experience (work and life), degree subject knowledge, skills and understanding, generic skills, emotional intelligence, self-confidence, and reflection and evaluation are factors that influence employability. Indonesian accountants need to enhance degree subject knowledge, skills and understanding, generic skills, and emotional intelligence, particularly in IFRS standards and communication skills. Managerial and theoretical implications are mentioned, as well as limitation and recommendation.
\end{abstract}

Keywords: Accounting, Employability, Mutual Recognition Arrangement

\section{INTRODUCTION}

In support of the ASEAN Economic Community, the Mutual Recognition Arrangement (MRA) was implemented in 2015 to enact professional certification and standardization among workers in select few professions; in particular, accountants. By having an internationally acknowledged skill verification, the MRA hopes to be able to circumvent the inherent differences in education system, cultural, and socio-economic situations across ASEAN member countries. A study by McCarthy [1] stated that graduates with verifiable skills would be able to find more opportunities than the ones without verifiable skills. Therefore, it is essential for ASEAN member countries to ensure its skilled professionals can attain a certain standard of quality and competency, to compete with the other employees from the other ASEAN members.

One of the most critical means for private sector development to attract foreign direct investors and to raise the confidence of domestic investors is through achieving sustainable public financial management reforms, as well as promoting a more effective corporate governance, accountability, and transparency. Research by Zaidi and Huerta [2] revealed that there is a positive correlation between the adoption of IFRS and the economic growth of the adopting countries as observed five years into implementation. Coffee [3] further supported the idea that improvement in transparency and accounting standards signified an increase in quality 
of the financial statements, which in turn strengthens investors' trust. Louangrath [4] believes that because accounting, finance, and business management are certifiable professions, they should, therefore, be prioritized in certification standardization. One such uniformity found enforced by ASEAN Federation of Accountants (AFA) is International Financial Reporting Standards (IFRS).

In 2013, the Indonesian Financial Accounting Standards Board (IFASB) released the following statement regarding the convergence of IFRS to the national Generally Accepted Accounting Principle (GAAP):

"Indonesia's stated policy is to maintain its national GAAP and converge it gradually with IFRSs, minimizing the significant differences between the two. Indonesia does not have a plan or timetable for full adoption of IFRSs" [5]

Although the implementation of MRA would be beneficial in enhancing labor mobility for skilled labor, the MRA also poses the problem of vulnerability to employment security as a result of heightened competition. Moreover, the capabilities of accounting professionals are not limited to certification paper. As more and more accountants acquire their international certificates, accounting professionals must also take into consideration employable skills that are often required from stakeholders. Employable skills can be described as skills or qualities that an employee develops through their work experience, years of training and education, interests or activities outside of work [6]. This raises the question of whether or not Indonesia, particularly in the accounting profession, is prepared for the employment challenges that will be presented by the implementation of the AEC. Currently, there is little information regarding the factors influencing the employability of the accounting profession in Indonesia.

While there may be many studies surrounding employability, there has been limited research on professional accounting in ASEAN, particularly in Indonesia. Furthermore, many of the studies found are based on questionnaires, offering a fixed set of skills and attributes to evaluate [7]. Lastly, most accounting professionals' employability studies found with regards to AEC are conducted in Thailand [8], which may not be representative of the Indonesian environment. Thus, this paper attempts to answer the following questions:

RQ1: What skills and factors influence the labor employability of Indonesian workers in the field of accountancy?

RQ2: How can Indonesian accounting professionals gain the competitive advantage among other certified ASEAN workers?

The remaining paper is sequenced as follow: literature review, research methodology, findings, conclusion, recommendations and future research.

\section{LITERATURE REVIEW}

\subsection{Comparative Study of DES, 3DES, AES and RSA}

Yorke and Knight [9] defined employability as:

"a set of achievements - skills, understandings and personal attributes - that make graduates more likely to gain employment and be successful in their chosen occupations, which benefits themselves, the workforce, the community and the economy" ( $p$. 3). 
Yorke and Knight's [9] definition lines up with the purpose of this paper; that is to determine, explore, and assess the factors influencing employability of Indonesian accounting professionals. As such, the study adopts Yorke and Knight's [9] definition of employability.

\subsection{Career EDGE Model.}

Career EDGE Model (Figure 1) is divided into two departments: Career EDGE and Reflection and Evaluation. Career EDGE is made up of career development learning; experience - work and life; degree subject knowledge, skills and understanding; generic skills and emotional intelligence [10]. Reflection and Evaluation focus on improving oneself through self-reflection and evaluation. Dacre Pool and Sewell [10] further suggests that deficiency in any one of the elements in the model will profoundly affect the individual's chance of employability.

\subsubsection{Career Development Learning}

Individual's ability to be self-aware, to understand their weaknesses and strengths to find the appropriate job, therefore securing jobs in which they can be successful and satisfied with their career decisions [10].

\subsubsection{Experience - Work and Life:}

Work-based learning or work-integrated learning through job completion [11]. Work experience allows employees to apply the knowledge they have accumulated into the practice setting. Additionally, vast work experience enables an individual to realize their potentials and shortcomings through trials and errors [12].

\subsubsection{Degree Subject Knowledge, Skills, and Understanding:}

The formal qualification of an individual. Dacre Pool and Sewell's [10] explained the Career EDGE model is based heavily on the theory that the more qualification an individual has, the higher their employment opportunities.

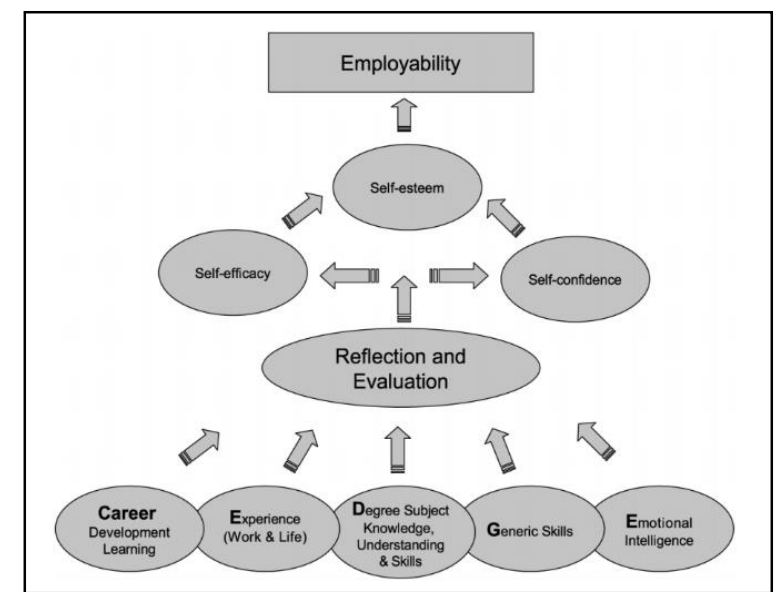

Figure 1. The CareerEDGE Model. [10] 


\subsubsection{Generic Skills}

Core or transferable skills. A degree or qualifications may be the standard for the job application, but may not sufficient in securing the job, even when the applicant possess a high GPA [13] Jackson [14] claimed that having highly valuable and irreplaceable skills will increase an individual's bargaining power in their career.

\subsubsection{Emotional Intelligence}

Eemotional competency or literacy [15]. Several studies acknowledge the importance of emotional intelligence as factor employability [10][15]. One study [16]] reported that a person's success in life is not fully dependent on their intelligence quotient (IQ).

\subsubsection{Reflection and Evaluation}

The idea that employees should instinctively reflect on and evaluate the experiences that they have gone through [10]. Reflection and evaluation are said to be the key to the development of self-efficacy, self-confidence, and self-esteem [10].

\subsubsection{Self-efficacy}

Believing in one's ability to coordinate and execute a given task to achieve a goal. Gibbs et al. [17] explain that previous experience will often affect one's judgment, which in turn determines how they deal with certain situations.

\subsubsection{Self-Confidence}

The "belief in one's ability to achieve one's goals" [18]. People with self-confidence are seen to be self-assured and comfortable with themselves.

\subsubsection{Self-esteem}

An individual's perception of themselves [18]. Employees with self-esteem are aware of their self-worth and are realistic in evaluating themselves [10].

\subsection{Human Capital Theory}

This study has adopted the framework of Human Capital Theory [19] supported by the theory of competitive advantage [20]. The main idea of Human Capital Theory is that education generates skills in potential employees and thus opens up employment opportunity. The human capital theory thus implies that improving one's skills "raises their attractiveness to potential employers and their likelihood of employment and earnings" [21]. According to Human Capital Theory, it is therefore important for Indonesian accountants to continue to raise their knowledge and skills to increase their attractiveness to potential employers.

Porter [20] defined competitive advantage as an advantage over the competitors gained by providing greater added value to consumers. An organization will be able to achieve a competitive advantage when it can outperform its competitors [20]. Researchers have proposed the notion that human resource management practices can contribute to competitive advantage [22]. 


\section{METHOD}

This research is exploratory research with the approach of the qualitative method through an in-depth interview. The research is conducted over a period of three months. During that period, data collection was executed over a period of 2 to 3 weeks. Due to the nature that the data was only be gathered once, a cross-sectional study is most suited to reach the objective of the research. The criteria for being interviewed are 1. currently working in the field of accountancy, and 2. have experienced labor mobility in ASEAN. Varieties in the sample target encourage the credibility of data as the finding provided different sources of perspective, thus illustrating a more comprehensive view. Table 1 shows the respondent demographics for this study. The primary data came from interviews. The researcher made use of data from a total of 11 individual interviews; 5 employees, three employers, and 3 ASEAN experts. Secondary data is gathered from academic journals, reports, and statistics to observe, understand, and analyze the issue of Indonesian accounting professional's employability.

Table 1. Respondent Demographics.

\begin{tabular}{llll}
\hline Pseudonym & $\begin{array}{l}\text { Respondent } \\
\text { Type }\end{array}$ & Occupation & $\begin{array}{l}\text { Years in } \\
\text { Industry }\end{array}$ \\
\hline Anna & Employer & HR Manager & 7 \\
Adam & Employer & HR Specialist & 5 \\
Agnes & Employer & HR Assistant & 2 \\
Bryan & Employee & Head of Internal Audit & 23 \\
Bobby & Employee & Accounting Manager & 12 \\
Beth & Employee & Financial Controller & 17 \\
Ben & Employee & Accounting Supervisor & 8 \\
Britney & Employee & Cost Accounting Specialist & 5 \\
Chris & Expert & The researcher at Atma Jaya Catholic University & 12 \\
Cindy & Expert & Researcher of ASEAN Studies Program at Habibie & 8 \\
& & Center & 10 \\
\hline
\end{tabular}

The interviews take the semi-structured format. Semi-structured interviews allow participants the freedom to express their views and opinions and a loose structure helps the interviewer to explore the answers further. The interviews were conducted in person and individually to observe facial expressions and body language from participants. The interviews were given the flexibility to ask further questions that may not have been written in the guided interview questions. The research questions used a conceptual model based on Sewell and Dacre Pool [23] to construct the interview questions. Figure 2 illustrates the conceptual model of this research. 


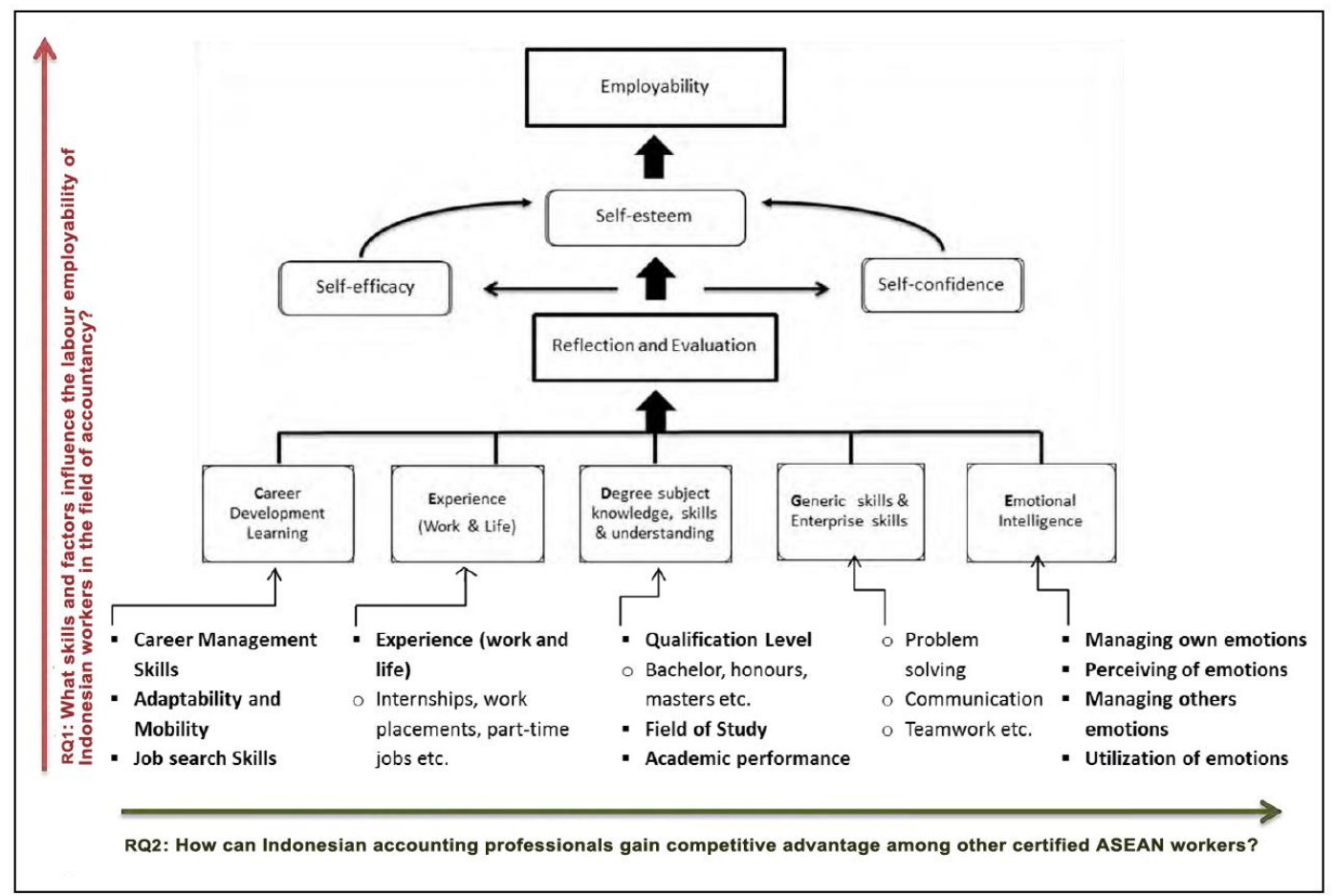

Figure 2. Conceptual Model of Individual Employability Factors adapted from [23]

The authors made use of data coding to look for patterns and emerging common ideas into themes and sub-themes. Recorded interviews were transcribed and annotated for timestamps during the meeting. Subsequently, codes were developed from the data collected. The codes are then compiled and analyzed for signs of different emerging themes and sub-themes. Finally, this paper analyses the issues in the collected data and offer a conclusion.

\section{RESULT AND DISCUSSION}

\subsection{Participant Demographics}

This study made use of 11 useable results comprising three employer, five employees, and three experts. Aliases are assigned to identify each participant's responses. An employer is given nicknames starting with the letter A, employees with the letter B, and experts with the letter $\mathrm{C}$ (e.g., Adam for the employer, Bryan for the employee, Chris for expert). The aliases correspond to their genders.

\subsection{Individual Employability Factors: Research Question 1}

\subsubsection{Career Development Learning.}

Results showed that career management skills affect the probability of a professional accountant's employability. Employers expect their potential hires to possess adequate written 
and social skills using CVs and interviews. Employers noted that by interviewing the candidates, they could gauge the communication skills of individuals as well as their confidence level.

“... especially at well-known companies like [organization], the HR department tend to receive a lot of resumes. It is therefore important to have a stricter selection process." (Adam)

These results are similar to research by Jackson [14] that explains career management skills affects the employment probability.

Job search skills, on the other hand, was not given much weight and attention as Career Development Learning. Experts reported that the majority of Indonesian professional accountants do not look for an overseas job opportunity as they feel more comfortable working in their home country.

“...there are a lot of Indonesian employees who have become too comfortable working domestically..." (Cindy)

Among the employees, four of them claimed to receive assignments to work in another ASEAN country after they have acquired a job in Indonesia, rather than finding a position located overseas. A definitive conclusion regarding job search skills could not be made based on the current data.

"I don't get to choose which projects to work on ... [organization] gives me the project here (in Indonesia) and then they send me abroad..." (Ben)

\subsubsection{Experience - Work and Life}

Similar findings were found as those from previous research [10][14]. This study found that all employers interviewed valued work experience very highly, one employer admitting to using it as a core selection tool for employment.

"Certificate is important, but sometimes certificate doesn't mean they know what they are doing. Work experience means we know they have experience in the working environment." (Agnes)

Parallel to previous research [12], interviewed employers reported that hired accountants with work experience could adjust to the work environment due to the previous work experience. Employees with work experience are perceived to be more mature and have a higher likelihood to acquire knowledge that can only be taught in a real work environment [11].

“...in my opinion, you can increase your skills as you do your job. Learning by doing." (Bobby)

One particular employee had reported to miss out on job opportunities due to not having sufficient work experience.

“...there were a lot of times where I had the qualifications required but not enough working experience.” (Britney)

However, this sentiment was argued by experts, stating that job opportunities for accountants are not limited to those with previous experience. One expert further explained that companies prefer to hire younger employees to train them at an early stage to conform to the company's ideals. 
"......even the fresh graduates now are being given the opportunity to work straight away in another country...” (Charlie)

“...the young ones can still adjust to new environment...can still be taught (new skills) compared to the seniors...." (Cindy)

Nevertheless, employee results, as well as employer results, showed that previous experience overseas affects the employability and job opportunity of a professional accountant to work abroad. These experiences can come in the form of prior work projects, overseas education, and living overseas.

"I received another project where the company is located in a country where I had studied my masters (degree). ...that could be one of the reasons why they entrusted me with the project..." (Ben)

The findings also suggest that people with international experiences feel that the experiences have had substantial impacts on their skills and characters. Four employees noted that through international experience, their communication skills have increased. Furthermore, all employees claimed to have a deeper understanding of the country's culture after working in said ASEAN country.

“... (Overseas experience) may not come as technical competencies, but at the very least it comes in the non-technical aspect of their capacity... " (Charlie)

The results correspond with previous studies [24] who suggest that prior work or life experience has a positive effect on employability; hence professional accountants who have acquired sufficient experience have a higher probability of securing employment rather than those with little to no experience.

\subsubsection{Degree Subject Knowledge, Skills, and Understanding}

Beyond achieving the basic level of tertiary education, there was not much evidence to suggest whether higher qualification levels increase employee chances of securing employment. Therefore a definitive conclusion could not be made based on the current data.

On the other hand, results showed that employers value accounting specific skills possessed by professional accountants. Employees that had demonstrated an understanding of particular accounting skills were preferred. According to a study [21], those showing noticeable knowledge and skills in their specific field areas have the higher chance of securing employment.

"... a set of the requirement when hiring employees, one of them is the understanding of IFRS and PSAK" (Anna)

This research found that on top of acquiring the fundamental accounting specific skills, value-added skill has shown the positive result in enhancing employee's career. This factor alludes to knowledge and skill that employees often acquire as they invest more time in their work environment, as well as skills they pursued out of their willingness to improve their work performance.

"A lot of [organization]'s client is Chinese, so I thought it would be beneficial for me to continue learning Mandarin....” (Ben)

Results also indicate that the accreditations and certificates belonging to a professional accountant plays a role in determining their chances of employment. A study [24] stated that some employers are more likely to recruit employees from credible institutions. On a similar 
tangent, both employers and employees result reported to consider credible accounting accreditations as a factor in determining professional accountant's employability.

"From the beginning, I knew I wanted to work overseas, so I had planned on taking a Certified Public Accountant (CPA) exam overseas from the start. Many public accounting firms will only hire CPAs." (Britney)

Two of the longest working accountants claim to have accumulated certificates with varying specializations. These accountants explained that while they feel that the certificates and qualifications they have are not essential to being an accountant, they help to boost their confidence because they think that the well-renowned accolades increase the credibility of their professional level.

"...I have two international certificates; Certified Fraud Examiner and Qualified Internal Audit. Both of these have no connection to reporting standards, but they give validations to my job" (Bryan)

\subsubsection{Generic Skills}

Results from employers and experts showed that given the future scenario of the similar level of technical skills that an ASEAN professional accountant could have, soft skills become a much more valuable attribute to differentiate one employee from another.

“... assuming that we are moving towards a standardized world including standardized professions, the technical skills should be similar. What is important is the non-technical skill..." (Charlie)

This concurs with researchers who explain that a degree or qualifications alone may not be sufficient in securing a job [13] and that employers look beyond a degree or requirements in potential candidates [22].

Each suggested variations of soft skills that they feel are needed for an accounting professional to have. Although there were some differences in the skills suggested, the results showed that there were some generic skills that were indicated in common by employers, employees, and experts. The set of skills were: work ethic, interpersonal skills, adaptability, and willingness to learn. 
The following Venn diagram shows the skills perceived to be essential for an accountant to have by employers and by employees, with the intersection highlighting common skills between the two.

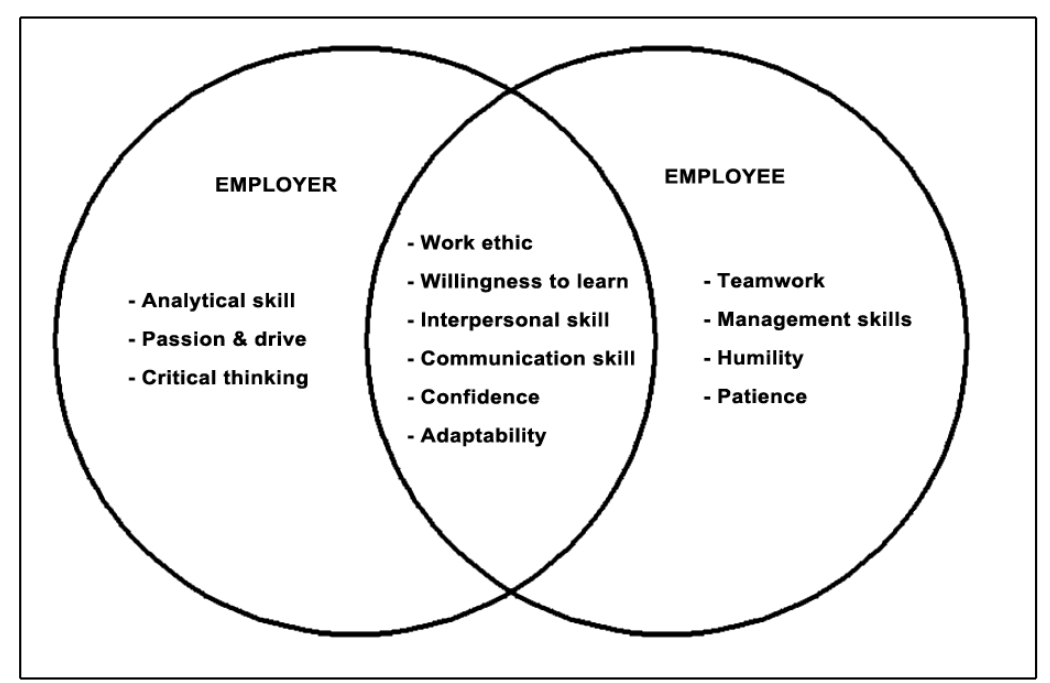

Figure 3. Employer vs. Employee skills.

\subsubsection{Emotional Intelligence.}

Results show that employers expect professional accountants to be emotionally intelligent, especially those who have previous experience working in the field before. Employees confirmed employers result by emphasizing the need to demonstrate emotional intelligence in their work environment.

"...how to deliver suggestions and ideas to my superiors without taking it personally when they reject it, and how to receive critiques without feeling victimized..." (Beth)

Results also showed that Emotional Intelligence helps in enhancing employee's career, increasing one's ability to work with others, while also improving one's productivity and the productivity of other co-workers.

"... when someone has low emotional intelligence; there will be friction within the team. When there is a lot of friction inside the team, the company's objective is neglected..." (Adam)

These results aligned with Dacre Pool \& Qualter [10] who claim that people with high levels of Emotional Intelligence have higher chance to be more successful in their careers than those who have lower levels of Emotional Intelligence.

\subsubsection{Reflection and Evaluation.}

All employers agreed that regular sessions for reflection and evaluation are needed for both the company and employee to develop. Employers explained that the purpose of employee assessment and evaluation is to measure an employee's job performance, whether or not an employee's skill set is appropriately matched to the employee's job. 
"...the idea is to push them to be their better self, to improve upon themselves. The goal is to help employees learn... once they achieve that, they will be able to meet [organization]'s mission and its values." (Adam)

Therefore, similar to Dacre Pool and Sewell's [25] research, reflection, and evaluation are considered to be a valuable factor in employee's self-development. Nonetheless, this study's result shows little evidence to indicate the importance of the employee's ability to self-reflect or self-evaluate. Instead, the result showed a particular emphasis on company administered appraisals.

\subsubsection{Self-confidence, Self-efficacy, Self-esteem}

Self-confidence was the most dominant factor between the three attributes; confidence, selfefficacy, and self-esteem. Employer and the expert result confirmed the importance of selfconfidence from their employees, also noting that self-confidence can be built on as the employee gain more experience. Furthermore, employees exhibiting confidence were reported to be able to adapt more easily and are taken more seriously than those who fail to exude confidence.

"...you have to have some level of self-confidence. Otherwise, you will crumble under pressure..." (Ben)

Self-esteem and self-efficacy were not perceived as heavily instrumental as self-confidence. In most cases upon landing a new job position or job location, employees were reported to be insecure. This seems to be even more evident for Indonesian professional accountants who had to catch up their skills and knowledge with other ASEAN accounting peers, attributing the insecurity to perceived skill and talent gap.

“...of course I was insecure when I first worked... especially my English wasn't excellent, and I had a lot of self-doubt in my skill....” (Britney)

However, employees admitted to having much higher self-esteem and self-efficacy upon their return from overseas. One employee claimed to have been an exemplary source of knowledge and experience for others to have their questions answered. This supports Archer and Chetty [26] who proposed that self-efficacy and self-efficacy is a result of growing work experience.

"... when I returned to Jakarta, I was the referential center for my peers because my skill in IFRS became better than them. I had already implemented it; they haven't." (Bryan)

\subsection{Employee Competitive Advantage: Research Question 2}

The findings in this study reveal that Indonesian professional accountant is still at an early development stage where existent skill gaps become the main hindrance in gaining competitive advantage. The interviewed employee stated that companies are more likely to hire the professional accountant from a more developed country if given a choice due to the skill gap. Therefore, this study concludes that for Indonesian professional accountant to increase the chance of gaining a competitive advantage, employees must work to close the skill gap between themselves and other ASEAN workers. 
“...before you talk about standing out among your peers, you need to first take a step back and make sure that you are up to standards...” (Charlie)

The expert confirmed data found from IFASB [5] suggests that there are differences in the standards set by ASEAN's MRA compared to the standards set by Indonesia's government.

"Our IFRS PSAK still has a one-year gap, the other standards are still being slowly adapted." (Charlie)

Indonesian professional accountants, therefore, need to be able to catch up with the constant changes set by IAI, as the Indonesian IFRS itself is also in the process of catching up with the current standards of ASEAN IFRS.

Gap in communication skills, more specifically linguistic skill, becomes the highlight of concerns for experts during interviews. Many respondents identified it as the primary factor in separating an accountant who is ready for AEC and those who are not prepared. To compete with other ASEAN accountants, Indonesian employees are advised to strive for a satisfactory level of English proficiency, especially the formal English most suited in the professional accounting field.

“...something we need to develop more for our professional accountants - the ability to speak professional English" (Charlie)

These results concur with previous research by Adhariani and Siregar [7] who suggested that language capabilities and soft skills were found to be most lacking amongst accountants in Indonesia.

\subsection{Research Findings Summary}

\subsubsection{Individual Employability Factors: Research Question 1}

The individual factors that affect the employability of professional accountants in Indonesia were found to be Career Development Learning, experience (work and life), degree subject knowledge, skills and understanding, generic skills, emotional intelligence, reflection and evaluation, and self-confidence. These factors bear similarity to most of the individual factors proposed by Sewell and Dacre Pool's [23] CareerEDGE model, with the difference in the exclusion of self-esteem and self-efficacy in the model as a result found little evidence to suggest the importance of having these factors. Furthermore, analogous to Human Capital Theory, further development in experience, degree subject knowledge, generic skills, and emotional intelligence to affect the probability of employment in another ASEAN country. These findings are illustrated in Figure 4. 


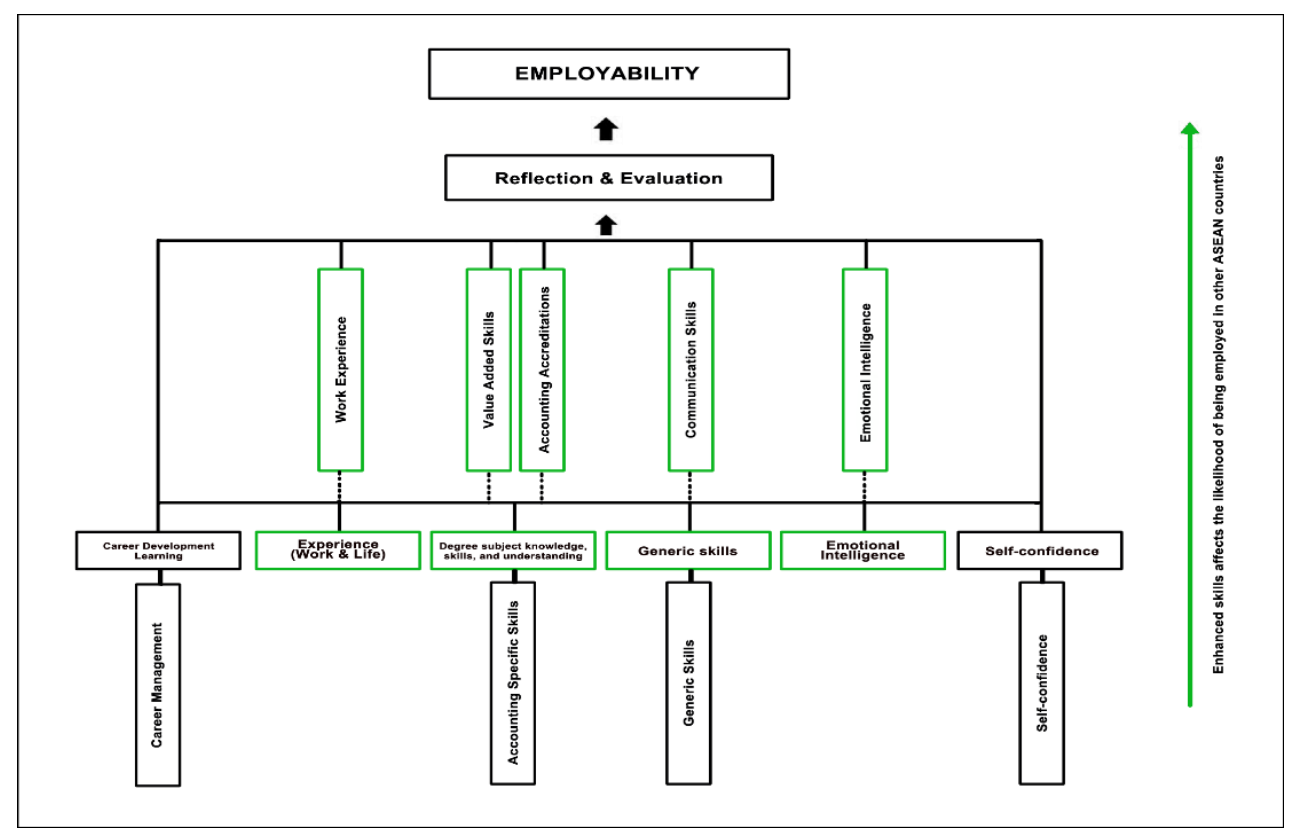

Figure 4. Professional Accountant Employability Factors.

(Model derived from the research findings and based on CareerEDGE model [23])

\subsubsection{Gaining Competitive Advantage: Research Question 2}

The overall findings illustrate that for Indonesian professional accountants to gain competitive advantage, they must first be well-equipped in covering the fundamental skills needed for ASEAN accounting field. The result found that Indonesian professional accountants will have difficulty in finding a competitive advantage in their skills if they do not have a robust set of skill foundation. The skill gaps identified in the interview findings include the gap in technical skills and gap in communication skills, mainly oral skills. Figure 5 below illustrates the need to minimize the lack of skills to gain a more significant competitive advantage.

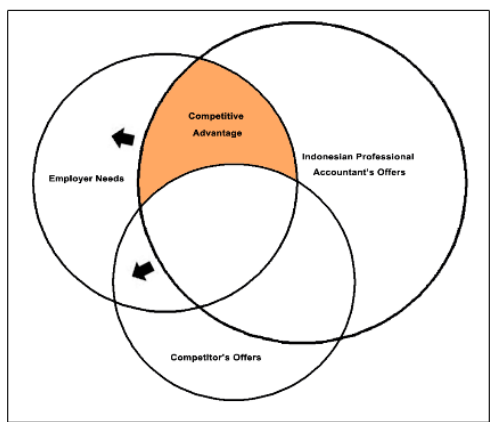

Figure 5. Gaining Competitive Advantage. 


\section{CONCLUSION}

The individual factors that affect the employability of Indonesian accountants were found to be career development learning, experience (work and life), degree subject knowledge, skills and understanding, generic skills, emotional intelligence, self-confidence, and reflection and evaluation. Additionally, further development in experience, degree subject knowledge, generic skills, and emotional intelligence were found to enhance the probability of overseas employment

Bridging the skill gap in technical skills and communication skills become the first step in gaining competitive advantage for Indonesian professional accountants. The smaller the gap in skills between Indonesian professional accountants and the other ASEAN professional accountants, the bigger the chance to enhance the competitive advantage.

\subsection{Recommendations}

Employers, universities, PAOs, and the professional accountants are recommended to cooperate closely to improve the skills for professional accountants to ensure that the skills achieved can compete with the other ASEAN counterparts. Individual professional accountants are encouraged to increase and improve their own set of skills, especially in regards to soft skills that both parties deem to be valuable. These soft skills as found in this study are work ethic, willingness to learn, interpersonal skill, communication skill, confidence, and adaptability.

Further, employees who seek employment opportunity in other ASEAN countries are encouraged to develop the necessary skills and knowledge that would not only be seen as viable in Indonesia but also in international settings. The study found that enhancing experience, improving accounting specific skills, obtaining accounting accreditations, gaining more soft skills, and maintaining emotional intelligence is vital in securing employment in another ASEAN country.

Indonesia is encouraged to integrate ASEAN cultural awareness into education and professional training programs to close the skill gaps, especially in regards to English linguistic skills.

Although AEC encourages standardization, Indonesian professional accountants are encouraged to establish a set of identity and characteristics through the enhancement of soft skills that could be used to associate them with.

Lastly, the accounting industry is urged to spur interest from accounting graduates to register themselves as Certified Professional Accountants. Assistance from academic institutions and the accounting industry can be offered by providing graduates with opportunities in the form of internships or overseas employment opportunity.

\subsection{Limitations}

The research was limited in scope and comprised of a small sample of 11 interviewees. The majority of interviewees worked in Jakarta. Hence the findings may not be a representation for all of Indonesia.

The lack of a readily available tool or measurement of employability resulted in interview questions that relied heavily on elements found in the literature review and the conceptual model in the literature review. The problems could have affected the perceptions or opinions among the interviewees, thus leading to a skewed result that does not necessarily reflect their real opinions. The results should be treated with caution. 


\subsection{Future Research}

For future researches, the investigation may be further explored using a much larger sample and extending it to other regions in ASEAN. The study could be applied to another field of a profession as well, not limited to professional accounting. The research can be recreated using a qualitative, quantitative, or mixed methods approach to re-assess and expand the framework.

\section{REFERENCES}

[1] R. McCarthy, "ASEAN integration: Let's not forget the implications foreducation," UNESCO Bangkok, 2013. [Online]. Available: http://www.unescobkk.org/education/news/article/asean-integration-lets-not-forgetthe-implications-for-education/. [Accessed: 18-Dec-2018].

[2] S. K. R. Zaidi and E. Huerta, "IFRS Adoption and Enforcement as Antecedents of Economic Growth,” Int. J. Account. Financ. Report., vol. 4, no. 1, p. 1, Apr. 2014.

[3] J. C. Coffee, "Racing towards the Top?: The Impact of Cross-Listings and Stock Market Competition on International Corporate Governance," Columbia Law Rev., vol. 102, no. 7, p. 1757, 2002.

[4] P. I. Louangrath, “ASEAN Economic Community - 2015: Economic Competitiveness for Sustained Growth and the Implication for Education Market," SSRN Electron. J., 2013.

[5] Indonesian Financial Accounting Standards Board, "Indonesian Financial Accounting Standards Board IAI 2013 IFRS Dynamics 2013 and Beyond: Impact to Indonesia Overview of IFRS convergence process In Indonesia." 2013.

[6] A. GRIP, J. LOO, and J. SANDERS, "The Industry Employability Index: Taking account of supply and demand characteristics," Int. Labour Rev., vol. 143, no. 3, pp. 211-233, Sep. 2004.

[7] W. Luekitinan, "Employability and job mobility: Critical skills for new graduates in ASEAN," Glob. J. Bus. Res., vol. 8, no. 5, pp. 1-8, 2014.

[8] M. Suttipun, "The Readiness of Thai Accounting Students for the ASEAN Economic Community: An Exploratory Study," Asian J. Bus. Account., vol. 7, no. 2, pp. 139-158, Dec. 2014.

[9] M. Yorke and K. Peter, Embedding employability into the curriculum. United Kingdom: The Higher Education Academy, 2006.

[10] L. D. Pool and P. Qualter, "Emotional self-efficacy, graduate employability, and career satisfaction: Testing the associations," Aust. J. Psychol., vol. 65, no. 4, pp. 214-223, Jun. 2013.

[11] B. Little, Employability and work-based learning. United Kingdom: The Higher Education Academy, 2006.

[12] A. Carbone and M. Hamilton, "Pizza with university ICT students," in Proceedings of the Australasian Computer Science Week Multiconference on - ACSW'16, 2016, pp. 19.

[13] L. C. Tan and E. French-Arnold, Employability of graduates in Asia: An overview of case studies Graduate employability in Asia 1-4. Bangkok: UNESCO Bangkok, 2009.

[14] D. Jackson, "Factors influencing job attainment in recent Bachelor graduates: evidence from Australia," High. Educ., vol. 68, no. 1, pp. 135-153, 2013.

[15] M. Bezuidenhout, "The development and evaluation of a measure of graduate employability in the context of the new world of work," University of Pretoria, 2011.

[16] N. A. Marzuki, C. S. Mustaffa, and Z. M. Saad, "Emotional Intelligence: Its Relations 
To Communication and Information Technology Skills," Asian Soc. Sci., vol. 11, no. 15, 2015.

[17] S. Gibbs, G. Steel, and A. Kuiper, "Expectations of Competency: The Mismatch between Employers' and Graduates' Views of End-User Computing Skills Requirements in the Workplace," J. Inf. Technol. Educ. Res., vol. 10, pp. 371-382, 2011

[18] N. K. Turner, "Development of self-belief for employability in higher education: ability, efficacy and control in context," Teach. High. Educ., vol. 19, no. 6, pp. 592-602, Mar. 2014.

[19] I. Fisher, "The Role of Capital in Economic Theory," Econ. J., vol. 7, no. 28, p. 511, 1897.

[20] M. E. Porter, Competitive Advantage, Creating and Sustaining Superior Performance. NewYork: The Free Press, 1985.

[21] M. Taylor, T. Haux, and S. Pudney, Skills, employment, income inequality, and poverty: Theory, evidence and an estimation framework. York: Joseph Rowntree Foundation, 2012.

[22] J. B. Barney, "Looking inside for competitive advantage," Acad. Manag. Perspect., vol. 9, no. 4, pp. 49-61, 1995.

[23] P. Sewell and L. D. Pool, "Moving from conceptual ambiguity to operational clarity," Educ. \$vmathplus\$ Train., vol. 52, no. 1, pp. 89-94, Feb. 2010.

[24] J. Kong and F. Jiang, "Factors Affecting Job Opportunities for University Graduates in China---the Evidence from University Graduates in Beijing," Res. World Econ., vol. 2, no. 1, Apr. 2011.

[25] L. D. Pool and P. Sewell, "The key to employability: developing a practical model of graduate employability,” Educ. \$vmathplus\$ Train., vol. 49, no. 4, pp. 277-289, Jun. 2007.

[26] E. Archer and Y. Chetty, "Graduate employability: conceptualisation and findings from the University of South Africa," Progressio, vol. 35, no. 1, pp. 136-167, 2013. 